\title{
FEJLESZTÉSI ELKÉPZELÉSEK ÓZDON ${ }^{1}$
}

\author{
(Development Scheme for Ózd)
}

\section{FÓNAGY JÁNOS}

A városfejlesztési koncepciók általában arról szólnak, hogy hogyan lehet egy város müködését jobbá tenni, az ott lakók életminőségét javítani. Ezek a koncepciók csokorba gyüjtik és elemzik az erőforrásokat, ezek gyenge és erős pontjait, meghatározzák a súlypontokat, iránymutatást adnak a részletes rendezési tervek készítéséhez, összeállítják a város marketing stratégiáját és egyéb más, e körben szakmailag elfogadott és elvárt kérdéseket. Ózd története arról szól, hogyan lehet egy város létét megōrizni és megindokolni, vagy ennek hiányában a lehetséges megoldásokat megtalálni. Tudomásul kell-e venni azokat a spontán folyamatokat, amelyek egy település esetleges megszünéséhez vezetnek.

Ózd története kőzismert: az 1840-es évektōl müködō kohászat és bányászat dinamikus fejlődése eredményeként a gyár körüli településekbōl 1949-ben várost hoztak létre, amely jelenleg - s talán ez kevésbé köztudott - a közel 50 ezer lakosával ma a megyeszékhelyeket leszámítva az ország egyik jelentős középvárosa. Közvetlen agglomerációjában - amelyre minden tekintetben kihat a város sorsa további 50 ezer ember él. Az ózdi probléma lényege, hogy Ózdon nem egy gyár szünt meg, hanem a kohászat és a bányászat leépülésével a település az értelmét, indentitását veszítette el.

A városnak, kialakulásával magyarázhatóan nem alakultak ki urbánus tradíciói. A város intézményrendszerét a gyár alakitotta, s a rendszerektől függetlenül lényegében a gyár tartotta fenn. A városnak nem volt o̊nálló értékrendje, lényegében nem volt polgári társadalmi struktúrája. Az értékrendet, az emberi kapcsolatokat, a társadalmi rétegződést is a mintegy 14 ezer embert foglalkoztató üzem határozta meg. A részletesebb ipartörténeti elemzés sem témáját, sem tartamát tekintve nem fér bele egy rövid ismertetőbe, de a probléma lényegéhez hozzátartozik, hogy a kohászatot és a bányászatot nem az ott és az abból élök tették tönkre. Az események egy szükségszerũ és világméretü folyamat részei voltak, nevezetesen az ipari forradalom klasszikus iparágainak tudományos, technikai meghaladottságának velejárói. A mi tőrténetünk ebböl a szempontból megegyezik Közép-Anglia, a Ruhrvidék vagy a pennsylvaniai iparvidék történetével. Amiben különbözünk ezektöl, az a gazdasági-társadalmi környezet nyilvánvaló eltérései mellett a felismerés és a racionális cselekvés különbségeiből adódott és adódik mind a mai napig.

A térség és ezen belül a város elött két választási lehetőség van:

- Beletőrődve tudomásul venni a spontán folyamatokat, engedni az urbanizáció életgörbéjének, amelynek leszálló ágát és végkifejletét az amerikai alaszkai aranyásó városok példájával szokták jellemezni.

- A másik lehetőség egy fảradságos, de tudatos tevékenység társadalmi generálása, a tudatos település- és területfejlesztés útján egy többség által elfogadott jövőkép kialakítása és annak megvalósitása. 
A tudatos cselekvést sürgeti a tény, hogy 28 település, ezen belül 2 város, $\mathrm{s}$ körülbelül 100 ezer ember sorsa múlik ezen. Többségüknek nincsenek mobilitási lehetőségei, hiszen a megye más települései, elsősorban Miskolc (Diósgyör) hasonló gondokkal küzd. A népesség szociális összetételében pozitív változás csak hosszabb távon várható. Gyakorlati szempontból meghatározóak az alacsony ingatlanárak, így alapjaiban hiányoznak a mobilitás szubjektív és objektív feltételei.

Ilyen körülmények között létkérdés a város és a kapcsolódó térség jövöképének kialakítása, a jövőkép elemeit meghatározó várospolitikai koncepció kimunkálása. Ózd város önkormányzata 1995-96-ban kidolgozta és elfogadta egy várospolitikai koncepció kialakításához szükséges föbb irányokat. Ennek keretein belül vizsgáltuk a várospolitikai stratégia, a jövőkép szerepét, a város jelenlegi helyzetét, identitását, a város funkcióit, a város gazdasági struktúráját és a népesség jellemzőit. Külön fejezetben foglalkoztunk a szegénység problémakörével, a város és a régió kapcsolatával, illetve a koncepció kialakításának föbb elemeivel és eszközeivel.

A jövőkép meghatározás, a lehetséges célok kijelölése és az azokkal történő azonosulás mellett azért is fontos, mert a napi politika kizárólag a rövid távú látszatmegoldásokban érdekelt, s csak egy hosszabb távú koncepció ad lehetőséget az éppen aktuális eszközök logikus, a jövőt szolgáló felhasználására. Minden eddigi kormányzati vagy más központi intézkedés lényegében érintetlenül hagyta a valódi problémákat. Ennek egyik oka lehet, hogy érzelmi identitású kérdésekre akartunk és akarunk olyan racionális válaszokat adni, amelyeket az érintettek nem fogadnak be. Tudatos, átgondolt cselekvésre van azért is szükségünk, mert Ózd és környéke számos okra visszavezethetöen - időt és teret vesztett: ma már a fél ország depressziós kategóriába tartozik, nem váltanak ki különösebb társadalmi hatást, még kevésbé szolidaritást az Ózdról sugárzott szocio-thrillerek. Ennek föbb elemei:

- a 18-20\%-os regisztrált, 35\% körüli tényleges munkanélküliség (utóbbira nincs pontos adat a politikailag determinált statisztikai fogalomalkotások miatt);

- 15-20\% körüli a cigány népesség, amelynek aránya a fiatalabb népességen belül eröteljesen növekszik;

- a népesség létszáma, mint korábhan utaltam rá, nem változik, de összetétele látványosan romlik: kedvezőtlenül alakul az idősek és fiatalok aránya, markánsan jelentkezik a képzettebb munkaerő elvándorlása, s egyre jellemzőbb az egyéni magatartásra az önfeladás. Az egyéni identitás zavara tömegméretüvé vált, megindult, egyes, korábban önálló településként fungáló városrészek elszakadása.

Ezek után mi adhat alapot egy elfogadható jövőkép kialakításához? A felbomló nagyüzem egyes egységeiböl megmaradt ipari bázis, amelyhez kapcsolódóan az elmúlt években számos kisebb-nagyobb olyan új vállalkozás jött létre, amelyeket alkalmassá lehet tenni az innováció befogadására. A város müködéséhez, térségi szerepvállalásához szükséges intézményrendszer az elmúlt években fizikailag megújult: új kórház, új posta, új telefonközpont, új rendőrség, új bíróság épült az elmúlt 56-évben Ózdon. Jó ütemben halad az Ózdi Ipari Park megvalósítása, amelyben jelenleg is már 70-80 kisebb-nagyobb vállalkozás müködik 3500-4000 munkavállalóval. Az elmúlt években kialakultak és több esetben országos modellként szolgálva sikerrel müködnek a gazdaságfejlesztő, válságkezelö 
intézmények, a vállalkozásokat segitö inkubátor rendszer, munkaerö átképző bázis. A város komoly erőfeszítésekkel, de megőrizte müködőképességét és intézményrendszerét. Ez utóbbin belül külön említést érdemel a színvonalas alap-és középfokú oktatási rendszer.

A jövőkép meghatározó elemei lehetnek tehát az egy-bázisra épülö település helyett egy, mind méreteiben, mind tevékenységében egymásra épülö ipari struktúra, a meglévő intézményrendszerekre alapozva a térségi szerep tudatos vállalása, és a megmaradást, a stabilizálást, majd később egy esetleges fejlödést lehetővé tevő, a humán és gazdasági elemeket komplexen kezelỏ gondolkodásmód és városirányitási politika elfogadtatása, illetve kialakitása.

A jövökép kialakítását a jelen problémáiból adódóan természetesen veszélyek is fenyegetik. A legfontosabbak ezek közül a szociális nyomásnak engedve, a nyomort konzerváló nagytömegü lapátos "munkahely" létrehozása, az értelmiség és a szakképzett népesség elvándorlásával további szellemi leépülés (nem véletlen, hogy a felsőoktatás kérdését válságkezelési eszköznek tekintjük és kíséreljük meg évek óta elfogadtatni).

A város megmaradási, fejlesztési stratégiájának kialakitásakor törekedni kell a konszenzusra, de ennek teljességét nem szabad fetisizálni. Nagyon eltérỏek a társadalmi csoportok érdekei, mind a várospolitika egyes elemei, mind azok megvalósitási sorrendje és elemzése tekintetében. Éppen ezért a végrehajtáshoz, konszenzust teremtö politikai és gazdasági erő szükséges.

\section{Jegyzetek}

${ }^{1}$ Az elöadás $A$ területi tervezés új kihivása: a területfejlesztési koncepció c. konferencián hangzott el. (Gyốr, 1997. április 3-4.) 